Historia i Polityka

Półrocznik poświęcony myśli politycznej i stosunkom międzynarodowym

Nr $10(17) / 201345-74$

DOI: http://dx.doi.org/10.12775/HiP.2013.012

Mariusz Kopczyński (Łódź)

\title{
„Absolutyzm” versus „polonizm” Bismarck, panslawizm a powstanie styczniowe
}

\author{
„Absolutism” versus „Polonism” \\ Bismarck, Pan-slavism and January Uprising
}

The aim of this article is to analyze attitude of the Prussian Prime-Minister - considered as the Architect of German Unification - Otto von Bismarck - towards the phenomenon of social rebellion, which in Polish history became known as the January Uprising. The intention of the Author is not to focus on issues related with wide-ranging diplomatic action of the prospective "Iron Chancellor", which was crowned with Alsvenlabena Convention. Bismarck was in the limelight not like as well-known „real politician”, but as a political thinker whom he also was. Author analyzes a highly specific conceptual nomenclature of Bismarck, and his attitude towards the Poles, Russians, Pan-Slavism and autocracy. Introduction to the subject is an overview of the evaluations of the insurrection, which was permanently established in Polish intellectual environments, including its traditional divisions between the right wing and the left wing.

Słowa kluczowe: Otto von Bismarck, myśl polityczna, powstanie styczniowe, panslawizm, samodzierżawie, Polacy, Rosjanie

Keywords: Otto von Bismarck, political thought, January Uprising, Pan-Slavism, autocracy, Poles, Russians

Rok 2013 ogłoszono Rokiem Powstania Styczniowego (Uchwała Senatu Rzeczypospolitej Polskiej z dnia 3 sierpnia 2012 r. ${ }^{1}$, Uchwała Sejmu Rzeczypospolitej Polskiej z dnia 4 stycznia 2013 r. w 150. rocznicę wybuchu Powstania Styczniowe$\left.g o^{2}\right)$. Treść obydwu tych publicznych wypowiedzi mieści się jednoznacznie w romantycznym nurcie ocen polskich zrywów niepodległościowych w XIX stuleciu.

1 Uchwała Senatu Rzeczypospolitej Polskiej z dnia 3 sierpnia 2012 r. ustanawiająca rok 2013 Rokiem Powstania Styczniowego (M.P. z 2012 r., Nr 0, poz. 588).

2 (M.P. z 2013 r., Nr 0, poz. 23). 
W Uchwale Sejmu padają określenia wysoce emocjonalne jak choćby, że było ono „aktem odrzucenia rosyjskiego jarzma” tudzież gdy czytamy że „Sejm Rzeczypospolitej Polskiej przypomina o cierpieniach ofiar represji rosyjskiego zaborcy, powstańcach skazanych na śmierć, zesłanych na Sybir, uwięzionych i pozbawionych majątku" (autorzy jakby zapomnieli, że były to skutki przegranego powstania, a nie jego przyczyny) przy jednoczesnej „internacjonalizacji” całego czynu, zwłaszcza gdy eksponowana jest „tradycja wspólnej walki o wolność”, która „stanowi jeden z filarów naszej współpracy i solidarności z narodami Europy, szczególnie z Litwinami, Białorusinami i Ukraińcami”.

W senackiej uchwale z kolei czytamy, że powstanie „było wyrazem sprzeciwu wobec carskiego ucisku i intensywnej polityki rusyfikacji" - rzecz całkowicie kuriozalna jeśli zważyć że wybuchło ono w czasie ewidentnych sukcesów polityki ugodowej Wielopolskiego, co nawet przyznaje przekonany wróg Rosji jakim był bez wątpienia Józef Piłsudski (1867-1935). „Cały aparat rządowy” - stwierdza on na swym odczycie z 20 I 1924 r. wygłoszonym w stołecznym kinie „Colosseum” - „stawał się polski, a odrodzona Szkoła Główna dotąd jest pomnikiem jego zasługi"”.

\section{Rok 1863 w tradycji intelektualnej prawicy i lewicy polskiej}

Chcąc usystematyzować ogół polskich ocen powstania styczniowego i uczynić to w nawiązaniu do tradycyjnych podziałów ideologicznych na prawicę i lewicę uzyskamy cztery możliwe stanowiska. Zacznijmy od strony lewej.

1. Apologetykę odnajdujemy w nurcie polskiej lewicy zwanym przez przeciwników „socjalpatriotyzmem”. Chwalcą powstania był choćby nestor tego ruchu Bolesław Limanowski (1835-1935) jako autor Historii powstania narodu polskiego w 1863 i 18644 , (Lwów 1882), książki, o której powiadano, że to "pierwsza z historii powstania pisana w duchu apologii czerwonych” . „Czyż wreszcie powstanie 1863 r.” - zadaje pytanie w innej ze swoich prac - „sprowadziło tylko same klęski? Utrzymywać coś podobnego - byłoby wielką niesprawiedliwością i niepraw-

3 J. Piłsudski, Wbór pism, (wstęp W. Suleja, K. Polechoński, wybór W. Suleja), Wrocław-Warszawa-Kraków 1999, s. 238. Całość ukazała się pierwotnie jako: J. Piłsudski, Rok 1863. Odczyt ogtoszony 20 stycznia 1924 r. w Warszawie, [w:] J. Piłsudski, Pisma wybrane, (t. 1-8), Warszawa 1924 , t. 6 , s. $148-167$.

4 B. Limanowski, Historya powstania narodu polskiego w 1863 i 1864, t. 1-2, Lwów 1882.

5 M. Romaniuk, Bolesław Limanowski (1835-1935), na stronie: http://lewicowo.pl/bolesław-limanowski-1838-1935, [dostęp dn. 29 VII 2013 r.]. 


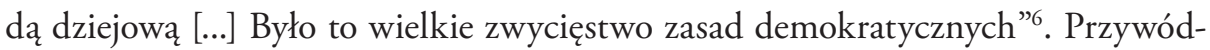
czyni natomiast par exellance internacjonalistycznej SDKPiL Róża Luksemburg (1871-1919) krytykuje powstanie, skądinąd w niespotykany dotąd sposób, jako ruchawkę polskiej szlachty przeciw uwłaszczeniu chłopów oraz rodzącej się burżuazji. Ale pamiętać należy, że w tych akurat opiniach pozostawała w sprzeczności z poglądami twórców komunizmu naukowego, którzy uwielbiali ustawicznie buntujących się Polaków podważających tym samym ład Świętego Przymierza. Friedrich Engels (1820-1895) pisał: „Wśród emigracji polskiej nie brakowało ludzi, którzy maja zapędy arystokratyczne; ale z chwilą gdy sama Polska włącza się do ruchu, staje się on na wskroś rewolucyjny, jak to widzieliśmy w latach 1846 i 1863. Ruchy te były nie tylko ruchami narodowymi. Ich bezpośrednim celem było zarazem wyzwolenie chłopów i przekazanie w ich ręce własności ziemskiej””.

Natomiast w PRL proinsurekcyjną politykę historyczną uprawiali narodowi komuniści z szeregów rządzącej partii. Tu za idealną egzemplifikację uchodzić może płk Zbigniew Załuski (1926-1978), jako autor Siedmiu polskich grzechów głównych ${ }^{8}$, który cały swój autorytet eksperta wojskowości kładzie na szalę by udowodnić, że powstańcza broń 1863 r. (głównie sztucer Enfielda pochodzący z zakupów w Anglii, Belgii i Austrii) przewyższała wartość uzbrojenia regularnej armii carskiej, w dodatku dozbrajającej się notorycznie na powstańcach (sic!) ${ }^{9}$

2. Nurt krytyczny. W PRL-u odnajdziemy tu tych wszystkich lewicowców, których Załuski określa mianem „szyderców”, mieszczących się w „tanim i łzawym humanitaryzmie, modnym niegdyś wśród części polskiej niekomunistycznej inteligencji postępowej”, a mianowicie „w jej pacyfizmie i powierzchownym antymilitaryzmie”. To każdy w jego obozie politycznym, kto „boi się ich i pogardza nimi [bohaterami]. Dlatego jest zawsze przeciwko walce, a po każdorazowej klęsce odczuwa

${ }^{6}$ B. Limanowski, Rozwój przekonań demokratycznych w narodzie polskim, Kraków 1906, [w:] Socjalizm jako konieczny objaw dziejowego rozwoju. Wybór pism, Warszawa 1989, s. 680-681.

7 Artykuł w „Der Volksstaat” nr 69 z 17 VI 1874 r., [w:] Marks i Engels o Polsce, Warszawa 1971, s. 309.

8 Zbigniew Załuski, Siedem polskich grzechów głównych, Warszawa 1962, wydanie drugie: 1963, trzecie: 1965, czwarte: 1968, piąte: 1973, szóste: 1977, siódme: 1980.

9 Największy chyba znawca problemu prof. Stefan Kieniewicz (1907-1992) potwierdza częściowo wersję Załuskiego co do niektórych mankamentów w szeregach wojsk rosyjskich: „Armia ta jeszcze nie zakończyła reorganizacji zapoczątkowanej po wojnie krymskiej i tylko w części została przezbrojona na nowoczesną broń gwintowaną [...]. Nie najlepiej stała dyscyplina w związku z rozluźnieniem karności mikołajowskiej i niewdrożeniem jeszcze nowych metod wychowawczych. Liniowi oficerowie nie byli przygotowani do walki z partyzantką, w której operować muszą samodzielnie niewielkie zgrupowania” - S. Kieniewicz, Powstanie Styczniowe, Warszawa 1983, s. 367. Ale twierdzenie, że Rosjanie musieli uzbrajać się na powstańcach by im sprostać, to już, wedle wszelkich znaków, licentia poetica Załuskiego. 
złośliwą radość z nieszczęścia: «a widzicie, po co wam to było?»"10. Siedliskiem lewicy wrogiej polskiej tradycji powstańczej jest w jego czasach warszawski klub „Stodoła”, gdzie wystawiono spektakl Król Ubu - Fantazja skandaliczna na tematy Alfreda Jarry’ego, który w surowej ocenie Załuskiego „stał się kpiną już nie z nauczania historii, lecz z samej historii, szyderstwem [...] ze wszystkich «nauczycieli»: starszych braci i ojców - czy ogólniej - przodków, ich wszystkich, całego ich dorobku, całego ich życia" ${ }^{\prime 1}$. Załuski pisząc te słowa w 1962 r. nie mógł jednak wiedzieć, że niedawni internacjonalistyczni i liberalizujący puławianie przeszedłszy na pozycje „komandosów” staną również po stronie polskiego etosu insurekcyjnego.

$\mathrm{Na}$ prawicy z kolei możemy dokonać następującego podziału:

1. Poglądy „realistyczne” wyrażało wielu polityków, teoretyków i publicystów a zrazu na myśl przychodzi główny oponent Piłsudskiego - Roman Dmowski (1864-1939). Stwierdza on: „Związek Rosji z Prusami powstał na gruncie rozbioru Polski. Gdy ten związek się rozluźnił pod wpływem antagonizmu w polityce zewnętrznej, gdy Rosja szła do zerwania Prusami, Polacy przez powstanie roku 1863 umożliwili Bismarckowi zacieśnienie przyjaźni na nowo"12. Najbardziej jednak w tej materii bezkompromisowy, bo sięgający znacznie głębiej był tutaj walczący z „kultem urojeń i fikcji” Aleksander Bocheński (1904-2001) autor słynnych Dziejów gtupoty w Polsce, pracy w które poddał bezwzględnej krytyce całą tradycję szaleńczych zrywów pod nonszalanckim okrzykiem: „Dziś twój tryumf albo zgon!”: „Przeciętny Polak przez 150 lat dałby się zabić za to, że to konfederacja barska, Sejm Czteroletni i Kościuszko ratowali, a Stanisław August i późniejsi ugodowcy ją zgubili, ergo, że naśladując tych «patriotów» barskich, działało się na korzyść Polski, a naśladując mądrego króla, na jej szkodę. Tak to u nas Historia była «vitae magistra»"13. Czy jeszcze czytelniej: „właśnie protektorat rosyjski dał

\footnotetext{
10 Z. Załuski, op. cit., s. 161.

11 Ibidem, s. 15.

12 R. Dmowski, Polityka polska i odbudowanie państwa, Warszawa 1988, t. 1, s. 131 [pierwot-
} nie jako: R. Dmowski, Polityka polska i odbudowanie państwa: $z$ dodaniem «Zagadnienia środkowoi wschodnio-europejskie» i innych dokumentów polityki polskiej z lat 1914-1919, Warszawa 1925]. Przywódca obozu narodowo-demokratycznego stwierdza również: „W opinii publicznej, która w kraju zapanowała, ostatnie powstanie uznane zostało na całej linii za akt szaleństwa, za poryw niedojrzałej młodzieży, podniecanej przez oderwaną od kraju emigrację, za wybryk nietrzeźwy, któremu starsze pokolenie skutkiem swego niedołęstwa i braku odwagi oprzeć się nie umiało” R. Dmowski, Niemcy, Rosja i kwestia polska, Częstochowa 1938, s. 3, [19081 - Towarzystwo Wydawnicze H. Altenberg, Lwów]. W tym miejscu lider endecji uległ złudzeniu, gdyż są to odczucia jego i grona zwolenników, lecz nie „opinii publicznej”, która en masse, pozostawała wierna kultowi klęsk narodowych i autotelicznego cierpiętnictwa.

13 A. Bocheński, Dzieje głupoty w Polsce. Pamflety dziejopisarskie, wydanie trzecie, Warszawa 1988, [1947', 1984²], s. 17. 
nam Radę Nieustającą, a i w przeddzień Sejmu Czteroletniego, podczas tego sejmu nawet, było możliwe otrzymać zgodę Rosji na dalsze poprawy ustroju" ${ }^{14}$.

2. Tu, w obozie apologetów powstań, znajdziemy z pewnością Piłsudskiego (oczywiście do prawicy należy wyłącznie „późny” Piłsudski). W czasach zbrojnych ekspropriacji, jako socjalista jeszcze, z odrazą wykluczał modus vivendi między Polakami a Rosjanami w ramach jednego państwa, Всероссийской Империи; za idealną egzemplifikację posłużyć mogą słowa użyte w słynnym liście do Feliksa Perla (1871-1927) pisanym podczas finalizowania przygotowań do napadu na pociąg pocztowy w Bezdanach. O perspektywie polsko-rosyjskiego pojednania powiada w nim, że ta: „ubliża mi jako człowiekowi z godnością nie niewolniczą”, a wszelkie na tym polu działania ze strony polskich realistów poczytywał sobie, może i nawet za „hodowanie... polskości”, ale mianowicie bardzo specyficzne gdyż zachodzące „w wychodkowej (nawet nie klozetowej) atmosferze”16. Polska racja stanu wymaga tedy nowych insurekcji, bo najważniejsza, jego zdaniem, jest „chęć zwyciężenia i przygotowanie zwycięstwa"17. W jego optyce postrzegania świata jeśli Polacy dają poklask hasłom pojednania z Rosjanami to nie może oznaczać żadną miarą że dojrzeli politycznie do nowej jakości, lecz tylko i wyłącznie, że: „Naród zaniemógł i opuścił ręce”18.

Poglądów swych nie zmienił również po opuszczeniu „czerwonego tramwaju socjalizmu”, to jest jako Naczelnik Państwa czy przywódca sanacji (vide: wspomniany odczyt z 1924 r.).

14 A. Bocheński, op. cit., s. 260. Oto inne wiodące myśli Bocheńskiego: „Ten zdumiewający fakt odzyskania kawałka wolnej ziemi pod słońcem, nie tylko bez pomocy żadnego z trzech rozbiorców, ale wbrew wszystkim trzem, utwierdził nieszczęsne mniemanie manifestu kościuszkowskiego: Polska może powstać tylko przez walkę ludu z trzema zaborcami, a zginać tylko przez... politykę i dyplomację. To przeklęte psychologiczne dziedzictwo epoki Legionów istniało przez 100 lat, a tliło się jeszcze w dwudziestoleciu Polski odrodzonej” (ibidem, s. 18). „Psychologia polska rozbudzona epoka legionów - cudownego odzyskania niepodległości - potem przybita upadkiem powstania, zaczyna oddalać się od wszelkiego myślenia, pada trupem psychozy zbiorowej, którą nazwano «mesjanizmem» [...]. Dopiero Wielopolski podnosi dawną myśl. Mając przeciw sobie wszystkich polityków rosyjskich i wszystkich polityków polskich, umie nakłonić Aleksandra II do odbudowania polski” (s. 20). „W Kongresówce, bez tych sukcesów, tą sama politykę lojalności przeforsował później twórca stronnictwa narodowodemokratycznego Dmowski. Niedługo stańczycy doczekali się miana zdrajców, a Dmowskiemu nieraz stawiano podobny zarzut” (s. 23).

15 J. Piłsudski, op. cit., s. 69.

16 Ibidem.

17 Ibidem, s. 70.

18 Opinia wygłoszona w Zakopanem 25/26 VIII 1911 r. - cyt. za: A. Garlicki, Józef Pitsudski 1867-1935, Kraków 2012, s. 220, [20081]. 
Jak widzimy z powyższej enumeracji akceptacja czynu zbrojnego sprzed stu pięćdziesięciu w polskiej tradycji stanowi zasadę, negacja wyjątek i do tego stanu świadomości dopasowane zostały wyżej wspomniane uchwały parlamentu.

\section{Rosja samodzierżawna jako archetyp}

Przedmiotem niniejszego artykułu jest analiza stosunku Bismarcka do powstania styczniowego, które pozostaje w szerszym stosunku ówczesnego premiera Królestw Prus do ruchu ideowo-politycznego, który swe credo zbudował na przeświadczeniu o praktycznych konsekwencjach płynących z kulturowo-językowych podobieństw narodów słowiańskich ${ }^{19}$. A wszystko to w nasuwającym się kontekście zagrożeń płynących dla kondycji niemczyzny wobec faktu zjednoczenia się Słowian. Warunkiem sine qua non powodzenia akcji panslawistycznej jest, zdaniem Bismarcka, trwałe polsko-rosyjskie porozumienie, jak powiada polsko-rosyjskie zbratanie (polnisch-rusische Verbrüderung), wszystko co tę wizję oddala, jest zbawienne dla niemczyzny.

Pozostali Słowianie widząc udany eksperyment pojednawczy między dwoma największymi a zarazem od kilku stuleci najbardziej zantagonizowanymi narodami Słowiańszczyzny, sami na Bałkanach mogą pokusić się o uzgodnione formy aktywizacji przeciwko wszystkiemu, co niemieckie w Monarchii Habsburskiej. Niemczyzna zostanie wzięta $\mathrm{w}$ gigantyczne kleszcze imperializmu pansłowiańskiego. Ale nawet bez jakiejś Jugosławii avant la lettre na Południu, sam sojusz Polaków i Rosjan (to znaczy modus vivendi w granicach Imperium w połączeniu z gromadnym ciążeniem Polaków z pozostałych zaborów w stronę Rosji) uniemożliwi zjednoczenie Niemiec a nawet sprawić może, że same Prusy zostaną wstrząśnięte w swoich podstawach.

Klucze do sukcesu tego największego antyniemieckiego przedsięwzięcia znalazły się więc w rękach ... Polaków i Rosjan. Dlatego ważne jest poznanie opinii premiera Prus i przyszłego kanclerza Rzeszy na temat obydwu tych narodów i jego rokowań co do perspektywy trwałego pojednania na gruncie wspólnej ich niechęci do żywiołu niemieckiego.

19 Termin „panslawizm” został po raz pierwszy użył słowacki filolog pastor Ján Herkel (1786-?) w pracy Elementa uiversalis linguae slavica. Buda 1826 [Literatura powinna być zrozumiała dla wszystkich Słowian „czyli prawdziwie panslawistyczna”, (sive verus panslavismus)] - A. Nowak, Między carem a rewolucją. Studium politycznej wyobraźni i postaw Wielkiej Emigracji wobec Rosji 1831-1849, Warszawa 1993, s. 271. 
Jak słusznie zauważył prof. Arkady Samsonowicz Jerusalimskij (1901-1965), tłumacz Gedanken ... na język rosyjski: „Ze swym praktycznym umysłem Bismarck bardzo wcześnie pojął jaką rolę na arenie międzynarodowej odgrywa Rosja. Jako polityk i dyplomata zrozumiał także, że Prusy nigdy nie będą mogły stać się mocarstwem (eine Großmacht), jeśli nie uda im się tego osiągnąć, by ich, w sprawach międzynarodowych bardziej wpływowy wschodni sąsiad, nie przyjął do tego pozytywnego nastawienia" ${ }^{20}$. Dodajmy, że w optyce Bismarcka Prusy miały stać się mocarstwem tylko po to, by uczynić Niemcy, a nie by powiększyć Prusy. W mej ocenie przypisanie Bismarckowi postawy rusofilskiej jest nadużyciem ${ }^{21}$. Bismarck nie tyle broni Rosji, co zdrowego rozsądku, gdyż a-intelektualizm uzasadnień przesłanek rusofobicznych ośmiesza Niemców - ich autorów, jak i krąg niewyrobionych odbiorców tego przekazu wewnątrz wspólnoty niemieckiej. Bismarck oponuje tej aberracji nie tylko „jako polityk i dyplomata”, co i myśliciel.

Bismarck znał Rosję, w tym z autopsji, gdyż mieszkał w niej przez trzy lata (1859-1862) jako poseł (der Gesandte) Królestwa Prus w stolicy carów ${ }^{22}$. Pierwsze wrażenie jakie odniesiemy, przysłuchując się narracji Bismarcka o wschodnim sąsiedzie to fakt postrzegania Rosji jako zwykłego europejskiego państwa. Oznacza to absencję złośliwości goszczących zwłaszcza u głosicieli teorii o polskim antemurale Christianitatis, imputującej mongoidalną („turańską”, wedle typologii Feliksa Konecznego) genezę ale i charakter państwowości moskiewskiej (z równą wrogością, bez oczywiście polskich kontrowersji Konecznego, opisywał ją Karol Marks³), czego prostą konsekwencją miało być zanegowanie słowiańskiego statusu ontologicznego imperium rosyjskiego.

Bismarck nie uznaje za zasadne kwestionować istnienia „rosyjskiego społeczeństwa" - (russische Gesellschaft), i to w zachodnim rozumieniu, choć wykazuje w tym pewną ostrożność. Nie czuje się jednak uprawnionym do snucia rozważań, które stawiałyby Rosjan poza marginesem europejskości.

20 A. Jerussalimski, Bismarck. Diplomatie und Militarismus, wydanie drugie (niezmienione), Berlin 1983, s. 39, [tyt. oryg. A. S. Jerussalimskij, Бисмарк: Аипломаиия имилитаризм, Moskva 1968].

21 M. Kopczyński, Między konserwatyzmem a nacjonalizmem. Myśl polityczna Ottona von Bismarcka (1815-1898), Toruń 2012 - zob. zwłaszcza s. 80-84 i 396-426.

22 Największą kopalnią wiedzy o tym okresie życia Bismarcka jest praca barona Borisa Emanułowicza Noldego (1876-1948) wydana przez B. Schulzego: B. Schulze (wyd.), Die Petersburger Mission Bismarcks, 1859-1862; Russland und Europa zu Beginn der Regierung Alexander II. Einzige vom Verfasser genehmigte und durchgesehene Übersetzung der im Jahre 1924 in Prag erschienenen russischen Ausgabe, R. Lamm, Leipzig 1936.

23 Karol Marks (1818-1882) przeciwstawiał „normańskość Rusi Kijowskiej” „azjatyckości Rosji Moskiewskiej” - zob. K. Marx, F. Engels, La Russie, (przedmowa R. Dangeville), Paris 1974, s. 42. 
Moment przybycia Bismarcka nad Newę (nastąpiło to 29 I 1859 r. po wcześniejszym odwołaniu z placówki we Frankfurcie nad Menem) nie przypadł na najbardziej sprzyjający okres. Ustąpienie westfalskiego Niemca, hr. Karla von Nesselrode ${ }^{24}$ który przez czterdzieści dwa lata pełnił funkcję ministra spraw zagranicznych Imperium dało asumpt do rozpoczęcia czystki obejmującej sfery decydentów w rosyjskim aparacie państwowym (naturalnie w proporcjach właściwych autokratyzmowi Romanowych, a nie bolszewickiej anihilacji) wymierzonej przeciw osobom narodowości niemieckiej. Choć akcji nie przeprowadzono zbyt rygorystycznie i sam nowy szef rządu, książę Aleksander Michajłowicz Gorczakow (1798-1883) ${ }^{25}$ nie przejawiał na tym polu przesadnej aktywności (niewątpliwie natomiast wspierał politykę Wielopolskiego w Królestwie Polskim), wzrost atrakcyjności haseł panslawistycznych stawał się trwałym komponentem rosyjskiej rzeczywistości. „Antyniemieckie nastroje młodszej generacji niebawem mnie i innym dały się odczuć również na obszarze stosunków politycznych, w głównej mierze, kiedy mój rosyjski kolega ks. Gorczakow zaczął demonstrować swą ogarniającą go zarozumiałość wobec mnie"26 - wspomina Bismarck.

W swej typologii Rosjan, precyzyjniej mówiąc: mieszkańców Rosji, gdyż sporo miejsca poświęca tamtejszej niemczyźnie, Bismarck wyróżnia trzy kategorie. „Najprzedniejszą stanowią europejscy i klasycznie wykształceni Grands Seigneurs z okresu rządów Aleksandra I”. Z przykrością stwierdza, że „byli na wymarciu (im Aussterben)". Do nich należy liczyć Mienszykowa, Woroncewa, Bludowa, Nesselrodego, a co ducha i wykształcenia tyczy, Gorczakowa, którego poziom, przez jego przesadną zarozumiałość nieco obniżonym był...”. Wszyscy oni „byli klasycznie wykształceni, mówili dobrze i biegle nie tylko po francusku, ale i po niemiecku i przynależeli do europejskiej śmietanki [Bismarck używa tu francuskiego słowa „la crême” - dop. mój - M.K.]”27. Bismarck ocenia Rosjan, więc postać czołowego eksponenta niemczyzny rosyjskiej, Karla von Nesselrode umieszcza gdzieś w głębi enumeratywnego wyliczenia. Jednak wiadomo, że w tej grupie jest on

${ }^{24}$ Karł Wasiljewicz Nesselrode (1780-1862) właśc. Karl Robert Graf von Nesselrode, urodzony w Lizbonie syn rosyjskiego dyplomaty narodowości niemieckiej i protestanckiej Żydówki, ochrzczony w wierze anglikańskiej (!), do końca życia nie nauczył się mówić biegle po rosyjsku, w latach 1814-1856 minister spraw zagranicznych Rosji. Zob. artykuł: U. Eich, Nesselrode, Robert Graf von, [w:] Neue Deutsche Biographie (NDB; 1953-2020(?), t. 1- 28(?)), Berlin 1999, t. 19, s. 74-75.

25 Sylwetce Gorczakowa, ministra spraw zagranicznych Cesarstwa Rosyjskiego z lat 1856-1882 poświęcona jest, z nowszych opracowań, monografia: W. Pałatnikow, Горчаков. (Пьедестал. Время и служение канилера Горчакова), Moskva 2004.

26 O. v. Bismarck, Gedanken und Erinnerungen, Stuttgart-Berlin 1922, t. 1, s. 254.

27 Ibidem, s. 249. 
najistotniejszy choćby z tego powodu, że jako pierwszy użył pojęcia „absolutyzm” (dokładnie: „monarchizm”) jako synonimu „antypolonizmu”, co potem rozbuduje w swych rozważaniach Bismarck. Głębokie słowa uznania również dla etnicznych Rosjan „z pokolenia Aleksandra I” stanowią jedynie kolejne nawiązanie do „idei roku 1813 r.” i braterstwa broni czasów wspólnych zmagań z napoleońskimi najeźdźcami.

„Druga generacja” - kontynuuje Bismarck - „która była rówieśnicza z cesarzem Mikołajem [chodzi oczywiście o Mikołaja I (1796-1855, od 1825 r. car) - dop mój. - M.K.] albo nosiła jego cechę, starała się w zachowaniu ograniczać do czynności dworskich, teatru, awansu (Avancement). Wśród nich są do wymienienia jako duchowo bliżej starszej [pierwszej - dop. mój - M.K.] kategorii stojące wyjątki: stary książę Orłow - wybijający się w charakterze, uprzejmości i zaufaniu dla nas, hr. Adlerberg ojciec i syn, [...] Peter Schuwałow, najbardziej wyrozumiała głowa, z którą tam wszedłem w stosunki i której tylko pracowitości brakowało aby odegrać kierowniczą rolę, książę Suworow, uprzejmy dla nas Niemców u którego rosyjski generał Mikołajewskiej tradycji [...] był doprawiony burszowskimi tradycjami niemieckich uniwersytetów [...] w końcu baron Peter von Meyendorff, dla mnie najbardziej sympatyczne zjawisko wśród starszych polityków, wcześniej poseł w Berlinie, który po wykształceniu i wykwintności form bardziej przynależał do epoki Aleksandryjskiej i który przez inteligencję i odwagę z młodszego oficera liniowego w wojnach francuskich, w których wziął udział, awansował do męża stanu, którego słowa u cesarza Mikołaja znacząco ważyły”28. Zauważmy, że Bismarck wyodrębnia kategorię poddanych rosyjskich, co do których swe nastawienie emocjonalne wyraża jedynie w kontekście ich stosunku do „nas Niemców” (nie używa nawet kamuflażu w postaci pruskiej raison d'état), bądź ich niemieckiej narodowości. Najbardziej niemiecki jest tu Peter von Meyendorff ${ }^{29}$ i tylko o nim wypowiada się w samych superlatywach. Jedyne ciepłe słowa pod adresem etnicznych Rosjan to pochwały za ich pozytywny stosunek do niemczyzny pod warunkiem, że takowy rzeczywiście dochodził do głosu w działaniach skonkretyzowanych przedstawicieli tej narodowości.

„Trzecia generacja, ta młodszych panów” - kontynuuje Bismarck - „pokazuje w swej towarzyskiej postawie najbardziej mało uprzejmości, zwłaszcza złe maniery i co do zasady silniejszą niechęć przeciw niemieckim a zwłaszcza pruskim elementom niż przy obydwu starszych generacjach. Jeśli się do nich, nie znając

28 Ibidem, s. 249-250.

29 Von Meyendorffa poznał Bismarck już wcześniej, gdy został zaproszony przez króla na święto rosyjskiego domu panującego w Berlinie, Peter von Meyendorff był wtedy rosyjskim posłem w Prusach, zob. L. Trzeciakowski, Otto von Bismarck, Wrocław 2009, s. 85. 
rosyjskiego, po niemiecku napomknie, to będą skłonni zaprzeczyć swej znajomości tego języka nieprzyjaźnie lub w ogóle nie odpowiadając" ${ }^{30}$. Tak więc po epokach Aleksandryjskiej, Mikołajewskiej i odpowiadającym im rosyjskim "generacjom” nadchodzi era Aleksandra II - „generacja młodszych panów”. Jest to czysty etnicznie element, który napłynął do rosyjskiego aparatu urzędniczego w miejsce zwalnianych Niemców. Coraz bardziej widoczna absencja tych ostatnich ma jakoby wpływać „zaniżająco” na ogólną kondycję narodu dominującego. Tym razem Bismarck nie wymienia nawet nazwisk - cała zbiorowość, jako, że nie ma wśród niej Niemców, spotyka się z jednoznacznym napiętnowaniem. To reakcja Bismarcka na krystalizujące się w świadomości Rosjan poczucie zagrożenia niemieckiego. Bismarck pragnie przerwać byt epoki „Aleksandryjskiej drugiej”, charakteryzującej się powszechnym awansem haseł panslawistycznych na dworze i w społeczeństwie. Tym ciosem stanie się konwencja międzypaństwowa na trwale związana z nazwiskiem generała Gustawa von Alvenslebena ${ }^{31}$, której sens nadało właśnie powstanie styczniowe przez sam swój wybuch, niezależnie od finału.

Drugi podział nie dotyczy wyłącznie „wyższego rosyjskiego społeczeństwa” (höheren russischen Gesellschaft), lecz ogółu mieszkańców Cesarstwa Rosyjskiego i powstał bezpośrednio na gruncie krytyki słynnego referatu Bunsena. Oponent Bismarcka to pruski dyplomata Christian Karl Joasis von Bunsen (1791-1860), który był „na tyle nieostrożnym, by w kwietniu [powinno być 1 marca - dop. mój - M.K.] 1854 r. nadesłać ministrowi Mannteuflowi długi memoriał, w którym, żądał utworzenia Polski, rozszerzenia Austrii aż po Krym, przeniesienia linii ernestyńskiej na saski tron i temu podobnych jeszcze, współdziałanie Prus dla tego programu zalecał ${ }^{32}$.

„W tym było postawione jako cel” - relacjonuje dalej Bismarck - „wedle którego Prusy jako szermierz Europy miałyby dążyć do rozczłonkowania Rosji, do utraty [jej] prowincji wschodnich, z włączeniem Petersburga do Prus i Szwecji, całego obszaru Rzeczypospolitej (Republik Polen) w jej maksymalnym rozszerzeniu i do zastąpienia resztek poprzez podział między Wielko- i Małorusów, nie zważając na to, że większość Małorusów przynależałaby już do maksymalnego obszaru Rze-

30 O. v. Bismarck, op. cit., s. 251.

31 Więcej na temat Gustava von Alvenslebena (1803-1881), generała i dyplomaty zob. B. von Poten, Alvensleben, Gustav von, [w:] Allgemeine Deutsche Biographie (ADB, t. 1-56, 1875-1912 Leipzig), Leipzig 1900, t. 45, s. 758 i n. oraz U. von Alvensleben, Alvensleben, Gustaw von, [w:] Neue Deutsche Biographie, Berlin 1953, t. 1, s. 233.

32 O. v. Bismarck, op. cit., s. 128. Więcej o postaci Bunsena, w latach 1841-1854 ambasadora Królestwa Prus w wielkiej Brytanii w artykułach: R. Pauli, Bunsen, Christian Karl Josias Freiherr v. [w:] Allgemeine Deutsche Biographie, Leipzig 1876, t. 3, s. 541-552 oraz W. Bußman Bunsen, Christian Karl Josias Freiherr von, [w:] Neue Deutsche Biographie, Berlin 1957, t. 3, s. 17-18. 
czypospolitej”. Dla usprawiedliwienia tego programu z lubością wykorzystywano teorię skądinąd przyjaznego Rosji Augusta Franza barona von Haxthausena - Abbenburga (1792-1866) („Studia o wewnętrznych stosunkach, życiu narodowym a szczególnie krajowych instytucjach Rosji”) ${ }^{33}$, że „trzy zony ze swoimi wzajemnie uzupełniającymi się produktami setce milionów Rosjan, jeśli ci pozostaliby zjednoczeni, musiałyby zapewnić przewagę nad Europą" ${ }^{34}$. Tutaj znów problem rosyjski przeplata się z wątkiem polskim lecz tylko Polska, nie Rosja jest dla Prus-Niemiec prawdziwym niebezpieczeństwem. Bismarck gdy mówi o przedrozbiorowej Polsce używa zawsze określenia „Republik Polen” dosłownie: „Republika Polska”, co zgodnie z przyjętym w polskiej historiografii nazewnictwem odpowiada znaczeniu „Pierwsza Rzeczpospolita”, kiedy zaś ma na myśli „Królestwo Kongresowe” posługuje się pojęciem „Polska Kongresowa” (Kongreßpolen) bądź „Królestwo Polskie" (Königreich Polen), gdy jedną klamrą spina Kongresówkę i Ziemie Zabrane mówi o Rußlandspolen („Rosyjskiej Polsce”, dosł. „Polsce Rosji”). Natomiast słowa "Polska” (das Polen) używa w dwóch znaczeniach, obydwu ksenofobicznych. Są to bądź wszyscy Polacy - obywatele państw zaborczych, którzy en masse wykazują wobec Niemców wrogie nastawienie, albo przyszłe państwo polskie („Polska” jako synonim restytuowanej „Republiki Polskiej”) gotowe zagrozić niemczyźnie. Polacy w przeciwieństwie do Rosjan są zwartą formacją etniczną, i mimo zamieszkiwania jako mniejszość w trzech różnych organizmach, nie dają się zredukować do węższych (a zwłaszcza zantagonizowanych) grup. Niemożliwym jest to do uczynienia ani na gruncie kryterium geograficznego, przynależności państwowej czy wybujałej dialektyzacji języka. Rzecz ciekawa: Bismarck uważa również Ślązaków za Polaków (tzw. „Wasserpolen” - „rozwodnieni Polacy”), choć przed rozbiorami nie mieszkali przecież w „Republice Polski”, z kolei odmawia tego miana Kaszubom - traktowanym na podobieństwo Łużyczan (Lausitzer) jako mikroskopijna grupa etniczna, „obca”, lecz o kolorycie folklorystycznym.

„Obcy z zewnątrz” w osobach Rosjan (Polacy to „wewnętrzni obcy”) zajmują tak wielki obszar, trudny do utrzymania w jednym kulturowym szablonie (przez ich własną władzę), że na przestrzeni wieków doszło do zaawansowanej dyferencjacji rosyjskich szczepów aż do pojawienia się zalążkowych postaci odrębnej świadomości quasi-narodowej wewnątrz wspólnoty. Ostatecznie doszło do wy-

33 Zob. A. F. v. Haxthausen, Studien über die innern Zustände, das Volksleben und insbesondere die ländlichen Einrichtungen Russlands, Hannover 1847. Więcej o autorze: A. Reifferscheid, Haxthausen, August Freiherr von, [w:] Allgemeine Deutsche Biographie, Leipzig 1880, t. 11, s. 119-121 oraz A. Elschenbroich, Haxthausen, August Franz Ludwig Maria Freiherr von, [w:] Neue Deutsche Biographie, Berlin 1969, t. 8, s. 140-142.

34 O. v. Bismarck, op. cit., s. 125-126. 
kształcenia się Wielkorusów i Małorusów. Bismarck jako fantasmagorie traktuje wysoce niepewne dowodzenia austriackie o istnieniu odrębnego (nierosyjskiego, choć słowiańskiego plemienia nad Dnieprem) określanego mianem „ruteńskiego” (rutenisch), a które to w następnym stuleciu wtargnie na salony europejskiej polityki jako „naród ukraiński”. Propaganda „ruteńska” być może zaspakaja habsburskie marzenia imperialne, (przecież Bunsen anglofil i wróg Bismarcka chciał dać Austrii $\operatorname{Krym}(!))$, ale nawet w jego referacie miało się to odbyć kosztem Rosji, a nie ontologicznie wątpliwej „narodowości” rusińsko-kozackiej!

Jeśli chodzi o geograficzne ramy fenomenu małoruskiego to Bismarck nie pozostawia tu precyzyjnych wskazówek. Ważne dla ich wychwycenia jest sformułowanie „maksymalny obszar Rzeczypospolitej” (Maximalgebiet der Republik Polen $)^{35} \mathrm{nb}$. stosowane zamiennie $\mathrm{z}$ „Rzeczpospolita w jej największym rozszerzeniu" (Republik Polen in ihrer größten Ausdehnung) ${ }^{36}$. Pełnią one rolę świadomych eufemizmów, by nie wymieniać daty 1772 r. i nie przywoływać niewygodnych wspomnień o nieistniejącym ogromnym sąsiedzie. Zresztą mówiąc o „największym rozszerzeniu” trzeba by sięgnąć znacznie dalej na wschód, niż wskazywałaby wschodnia delimitacja przedrozbiorowa. Innymi słowy, Małorusini to etniczni Rusini, których najpierw inkorporowało Lietuvos Didžioji Kunigaikštystè w realizacji programu podbojów nadczarnomorskich, a potem Rzeczpospolita Obojga Narodów/ Abieju Tautu Respublika którą Bismarck nazywa Republik Polen. Kilkaset lat pozostawania w obcym organizmie (organizmach) państwowych pozostawiło ślady w ich życiu typu zbiorowego. One też zaważyły na poczuciu odrębności od Rosjan spod władzy Rurykowiczów i Romanowych. Bismarck w polemice ze zwolennikami „rozczłonkowania” (Zerstückelung) Rosji, podkreśla niewykonalność tych zamiarów zważywszy na brak antagonizmu małorusko - wielkoruski, który mógłby tu posłużyć za oś podziałów. Nadto restytucja Polski jako kraju aż po granice sił witalnych zaangażowanego na wschodzie, czyli z aspiracjami terytorialnymi stymulowanymi w nie-niemieckim kierunku, wymagałoby na powrót oddania pod jej zwierzchność Małorusów. Wtedy z pozostałości imperium nie dałoby się wykroić żadnych zon, gdyż głębiej znajduje się homogeniczny mur Wielkorusów, a w Rosji, w przeciwieństwie do Niemiec, nie istnieją „dynastyczne wspomnienia” (dinastischen Erinnerungen) po władcach Tweru, Riazania ani „dynastyczne przywiązanie" (dinastische Anhänglichkeit) do ich zstępnych, tudzież republikańskie reminiscencje z czasów niepodległości Nowogrodu czy Pskowa. Owe „zony” mogłyby być jedynie liniami na mapie naniesionymi przez zwycięzców nie

\footnotetext{
35 Ibidem, s. 126.

36 Ibidem, s. 125.
} 
mających konceptu co uczynić z ofiarą. Ponadto Rosja bynajmniej nie zamierzałaby stać bezczynnie - losy tzw. Wielkiej Armii z 1812 r. winny dać tu dużo do myślenia. Bismarck podkreślał, że Rosja po Piotrze Wielkim, w przeciwieństwie od reszty państw ma dwie głowy: europejską - Sankt Petersburg i azjatycką - Moskwę, a zwycięstwo wymagałoby uchwycenia ich obydwu naraz, co jej militarną niemożliwością.

Tak więc Niemcy są skazane na wieczyste sąsiedztwo z Rosją. Jedyne co mogą uczynić to zadbać, aby była to znośna koegzystencja, ale na to duży wpływ ma okoliczność, która kategoria Rosjan (z drugiego jego podziału) tzn. „absolutyści” czy „panslawiści” zwycięży u sterów władzy. Jeśli dotychczasowa delimitacja nie była pograniczem w ogniu to pilnować należy, aby Rosja (w sensie czynników sprawczych państwa) nie uległa pokusie sięgnięcia po potężny oręż ideologiczny antyniemieckich panslawistów - owej „trzeciej generacji” według typologii Bismarcka. Trzeba sprawić wszystko, aby trwała ona niezmiennie w swej dotychczasowej tradycji dobrych kontaktów i idei braterstwa broni $1813 \mathrm{r}$.

„Rosyjska polityka” - czytamy w liście do Wilhelma I z 7 IX 1879 r. - „odkąd kraj przebolał skutki wojny krymskiej i odkąd jednocześnie panslawistyczna partia przewrotu (panslawistische Umsturzpartei) zyskała na wpływach, przybierała coraz bardziej niebezpieczny charakter dla pokoju europejskiego. Pokój europejski od upadku Napoleona nie był od nikogo tak wyjątkowo zagrożony jak od słowianofilskiej Rosji (slawophilen Rußland). Jest tak, jakby Rosja, pod kierownictwem słowiańskiej propagandy, przejęła dziedzictwo napoleońskiego cezaryzmu a z tym i misje, by tworzyć czarne punkty na horyzoncie europejskiego pokoju" ${ }^{37}$.

\section{Rosja panslawistyczna jako „rewolucja”}

Perspektywa wprawiająca Bismarcka w stan niepokoju to możliwość wyjścia Imperium z jego dotychczasowych kolein rozwojowych, wskutek moralnych podbojów w społeczeństwie rosyjskim przez „panslawistyczną partię przewrotu” (panslawistische Umsturzpartei), czy też jej powodzenia w otoczeniu Imperatora WszechRosji. W rozumieniu Bismarcka, między tradycją rosyjskiego Самодежавия a panslawizmem zachodziły tak głębokie sprzeczności jak między a la grâce du Dieu monarchią Burbonów a cezariańskim bonapartyzmem. Realnopolityczna różnica polegała na tym, iż z punktu widzenia interesów Niemiec wrogiem była

37 Cyt za: M. Stürmer (wyd)., Bismarck und die preussisch-deutsche Politik 1871-1890, München 1973 , s. 147. 
każda Francja, a Rosja tylko na wypadek zwycięstwa propagatorów wszechsłowiańskiego braterstwa.

Konieczna staje się eksplikacja trzech kluczowych pojęć: „panslawizmu”, „polonizmu” i „absolutyzmu”, a raczej znaczeń, jakie nadawał im Bismarck. W języ$\mathrm{ku}$ „realnopolitycznym” polemiki z panslawizmem „absolutyzm” funkcjonował bowiem nie jako synonim centralizmu biurokratycznego państwa, jak było to w przypadku Francji, a nawet rodzimych Prus, lecz w roli naturalnej przeciwwagi dla „polonizmu” (der Polonismus). Ten ostatni z kolei nie oznacza jakiejś polskiej perspektywy, jak można mylnie mniemać (czy nawet polskiej etymologii jakiegoś słowa), lecz etnicznie rosyjski kierunek filopolski. Natomiast tam, gdzie zazwyczaj stosuje się termin „absolutyzm”, [(w przypadku Rosji prawidłowo jest mówić o „władzy samodzierżawnej” (Самодержавной Bласти)] ${ }^{38}$ Żelazny Kanclerz używa określenia „autokratyzm”.

Wyjaśnić należy również, już tym razem nie koniecznie w kontekście Bismarcka, wzajemne relacje pojęć „słowianofilstwo” i „panslawizm”, gdyż budzą one spory. Nawet znawca tematu Andrzej Walicki - nie daje tu jednoznacznej odpowiedzi przyznając, że „słowianofilstwo było nieraz wręcz utożsamiane z panslawizmem, z wyraźną szkodą dla zrozumieniu obu tych kierunków. Stosunek słowianofilstwa do panslawizmu jest relacją złożoną, występującą w różnych postaciach u różnych ideologów i w różnych okresach"39. Pomijając meandry sporu należy używać te pojęcia jako zbliżone, do siebie, w panslawizmie widząc dojrzałą i lgnąca do syntezy z państwem absolutnym, postać wcześniejszego słowianofilstwa.

Zacznę od zwrócenia uwagi, że Bismarck nie stosuje determinanty geograficznej w sensie przypisywania znaczeń różnym kolejom losów poszczególnych segmentów Słowiańszczyzny. Nie interesują go również różnice opinii w obozie panslawistycznym, jeśli poglądy te nie rzutują na stosunek elit rosyjskich do „kwestii polskiej" (polnische Frage). Na temat różnic zdań między prof. Michaiłem Katkowem $^{40}$, który demaskował „dywersyjny” charakter serbskiego nacjonalizmu wobec

38 O drugim, na Zachodzie - nie tylko w czasach Bismarcka - zupełnie nieznanym, duchowym wymiarze „samodzierżawia” czytaj w: Metropolita Joan (Snyczow), Самодержавие Ауха. Очерки русского самосознания, Sankt-Pietierburg 1994, [1996²].

39 A. Walicki, W kregu konserwatywnej utopii. Struktury i przemiany rosyjskiego stowianofilstwa, Warszawa 1964, s. 399.

40 Michaił Nikoforowicz Katkow (1818-1887) - pionier rosyjskiej publicystyki opiniotwórczej, wydawca, działacz polityczny i krytyk literacki, syn rosyjskiego urzędnika i matki pochodzenia gruzińskiego; redaktor periodyku „Московские ведомости” („Wiadomości Moskiewskie”), współredaktor „Русского Вестника” („Posłańca Rosyjskiego”), piewca samodzierżawia i jednocześnie zwolennik sojuszu z republikańską Francją, wróg Polaków i ich „spisku jezuickiego”, niechętny również Niemcom. Zob. Русские писатели. 1800-1917. Биографическийсловарь, t. 1-4 (Moskva 
zdrowych odruchów narodowych Bułgarów, Iwanem Siergiejewiczem Aksakowem (1823-1886), wróżącym Czarnogórze rolę bałkańskiego Piemontu, jeśli ta podporządkuje sobie Hercegowinę czy pomysłów Konstantego Siergiejewicza Aksakowa (1817-1860), by włączyć do Rosji Rumunię jako przeszkodę w bezpośrednim styku ze Słowianami południa, nie wypowiadał się w ogóle. Podobnie nie skłania go do zajęcia stanowiska polemika między zwolennikami federacji pansłowiańskiej, inkorporacji do Rosji czy, jak u Dymitra Iwanowicza Iłowajskiego (1832-1920) ${ }^{41}$, niepodległego bytu poszczególnych narodów po upadku Porty i Habsburgów. Nie zajmowały go niuanse doktryny panslawistycznej, lecz możliwości jej oddziaływania na kręgi dworskie, gdzie znajdowały się rzeczywiste gremia kierownicze Imperium a i w tym przypadku zainteresowania skupione są wyłącznie wokół stosunków polsko-rosyjskich i możliwych płynących z tego zagrożeń.

Największym z nich jest dla niemczyzny quasi-apokaliptyczna perspektywa polsko-rosyjskiego zbratania (polnisch-rusischen Vebrüderung). Jego doniosłość nie wynika z tego, że wielkie imperium rosyjskie pozyskując sympatię akurat grupy autochtonicznej z Królestwa Kongresowego stanie się mocniejsze i bardziej skonsolidowane. W przypadku zwycięstwa orientacji prorosyjskiej wśród Polaków (co byłoby logicznym następstwem tryumfu postaw filopolskich nad Newą) na horyzoncie rysują się dwa potencjalne niebezpieczeństwa dla Prus i całych Niemiec.

Jedno z nich oznacza możliwość wykorzystania „obcych” z Poznańskiego, Śląska i Prus Zachodnich jako pasa transmisyjnego imperializmu rosyjskiego w dziele zaspakajania jego własnych autotelicznych ambicji. Problem z tym związany to brak ściśle określonych granic ekspansji kosztem niemczyzny, nieobecnych tak w doktrynie naiwnych słowianofilów, jak i agresywnych panslawistów rosyjskich. Bismarck, w swym zamyśle geopolitycznym, oznaczył precyzyjnie $l i$ mes niemieckich dążeń terytorialnych na kierunku środkowo-wschodnim wzdłuż rzeki Prosny, a więc akceptował porządek powiedeński jako nienaruszalny i satysfakcjonujący. Kiedy więc spoglądał od strony zachodniej na Komorę Celną I Stopnia w miejscowości Александров Пограничньй (ро Wielkiej Wojnie nowe władze dekretem Naczelnika Państwa z 4 II 1919 r. zmieniły nazwę na Aleksandrów Kujawski), to dostrzegał w niej słupy Heraklesa niemieckiego Drang nach Osten. Tu doznawało ono swego pryncypialnego zakończenia - nec plus ultra! Niemieccy fabrykanci Kongresówki byli dla niego wektorem niemieckiego biznesu a nie awangardą niemieckiej kultury szykującą przedpole dla dalszych podbojów;

1989-1999); Советская энциклопедия, Moskva 1992, t. 2, s. 506-513; L. Bazylow, P. Wieczorkiewicz, Historia Rosji, Wrocław 2005 [1969'] , s. 253-254 oraz 279.

41 Szerzej na ten temat: L. Piątkowski, Rosyjska myśl społeczno-polityczna wobec kwestii narodowej w Europie w latach sześćdziesiątych XIX wieku, Lublin 1985, s. 109, 122. 
kurlandzcy baronowie w najlepszym razie ludźmi łagodzącymi zapędy Romanowych na odcinku niemieckim.

Mamy na to dowód w postaci bezpośredniej relacji: „Cesarz Aleksander był wtedy [rozmowa miała miejsce w 1862 r. - dop. mój - M.K.] skłonny częściowo zrezygnować z Polski - powiedział mi to oschłymi słowami, przynajmniej odnośnie lewego brzegu Wisły, przy czym nie kładł na to akcentu, Warszawę wyłączywszy, która wszakże jako garnizon w armii miałaby swój powab a strategicznie przynależałaby do trójkąta twierdz nad Wisłą. Polska była" - kontynuował wedle relacji Bismarcka car - „źródłem niepokojów (Quelle von Unruhe) i europejskiego niebezpieczeństwa dla Rosji, rusyfikacja jest nie do przeprowadzenia z powodu [...] braku administracyjnej zdolności rosyjskich organów. U nas udało się polski obszar zgermanizować (?) [znak zapytania pochodzi od Bismarcka - dop. mój - M.K.], mamy jakoby ku temu środki, gdyż niemiecka ludność jest bardziej wykształcona niż polska. Rosjanin (natomiast) nie czuje koniecznej przewagi, by rządzić Polakami, trzeba się więc ograniczyć do minimum polskiej ludności, jakie dopuszcza geograficzne położenie, a więc do granicy na Wiśle i Warszawy jako przyczółka"ł2. Bismarck wyraził całkowite désintéressment wobec oferty cesarskiej i należy z całą mocą podkreślić, że była to jego reakcja sprzed zjednoczenia Niemiec, a więc zanim Rewolucja Odgórna (Revolution von oben) przeszła w asekurancką fazę „wewnętrznego złożenia Rzeszy” (innere Reichsgründung) wewnętrznego złożenia Rzeszy”, w której to wedle oceny Lothara Galla „Wichrzyciel Europy [...] przekształcił się [..] w krótkim czasie w swego rodzaju gwaranta jej ładu”’33. Bismarck zastanawiał się jedynie nad tym czy car snując tak zaskakujące sugestie, konsultował się z kimkolwiek, co było istotne w kontekście badania nastrojów czynników oficjalnych Imperium Rosyjskiego. Wyczuwał instynktownie, że zagrożenie panslawizmem nie pochodzi od dworu, lecz od ideologów i publicystów, którym jednak może się udać zawładnąć rządem dusz Rosjan, również tych ze szczebli decyzji i jej realizacji. Dodajmy, że do podejmowania wątków neo-krzyżackich i ekspansji w kierunku bałtyckim podchodził z podobnym zobojętnieniem. W latach osiemdziesiątych w rozmowie z byłym gubernatorem cywilnym Liwonii, Augustem Georgiem von Oettingenem (1823-1908), utyskującym na wzmagający się nacisk rusyfikacyjny, stwierdził, że „nie jest w stanie uczynić cokolwiek dla tamtejszych Niemców”. Po czym dodał: „gdybym mógł, wyznaczyłbym premię za przeprowadzenie każdego Niemca z prowincji bałtyckich do

\footnotetext{
42 O. v. Bismarck, op. cit., s. 352.

43 Cyt. za: L. Gall, Bismarck. Der weisse Revolutinär, Berlin 1995, s. 520.
} 
nas"44. Gdy z podobnymi żalami pod adresem nowego kursu w Rosji zgłosiła się doń deputacja Niemców wołżańskich miał, ku jej konsternacji, do zakomunikowania, że obowiązkiem rosyjskich Niemców jest... dbanie o dobry stan stosunków niemiecko - rosyjskich(!) Powiedział: „Nie chcemy od nich [to jest Rosjan - dop. mój - M.K.] niczego; Polaków mamy dość, Rosjanom zaś nie potrzeba Królewca ani Poznania”45. Niekiedy przejawy antyniemieckiej polityki wewnętrznej caratu traktował z ironią: „dla nas być może tylko korzystne, gdy Rosja przez zniszczenie swej bałtyckiej podpory w postaci generałów i mężów stanu stanie się impotentem"46. Tak czy inaczej Hamuck нa Bocmoк nie musiał już niepokoić czynników rządowych nad Newą.

Dla Bismarcka Drang nach Osten był co prawda zjawiskiem ocenianym pozytywnie (w przeciwieństwie do krucjat), lecz zamkniętym historycznym doświadczeniem, do którego nie należało już wracać.

Narodziny rosyjskiego „parcia na Zachód” (Hanop нa 3anad) nie daje się bowiem ująć jako zjawisko przewidywalne w perspektywie celów ostatecznych. W skrajnym rozwinięciu wyobrazić sobie możemy jak rozgorączkowani rosyjscy nacjonaliści przywołają z pozaziemskiego wymiaru postacie Jaksy z Kopanicy, księcia Drażka czy księcia Niklota, by następnie obwieścić marsz ich „spokrewnionych" sukcesorów po ojcowiznę Obodrytów i Wieletów-Luciców. Jeden z panslawistów, Aleksandr Hilferding (1831-1872) nawołując „braci bałkańskich” do większej ufności wobec Rosji ostrzegał, aby w razie prób pójścia własną drogą nie zniknęli jak „Słowianie zamieszkujący niegdyś ziemie położone na zachód od Odry"'47. To jeszcze nie pogróżka pod adresem niemczyzny, lecz wyraz wiecznej pamięci i sygnał zarazem, że panslawizm w swej zdobywczości może przyjąć zupełnie niewyobrażalne kształty.

Mimo wszelkich obaw Bismarck unika demonizowania Rosji nawet gdyby ta zaczęła dryfować od „absolutyzmu” do „panslawizmu” W swej polemice ze stronnictwem anglofilów stwierdza, że „Z osiągnięć «Tygodnika Pruskiego» ${ }^{48}$

${ }^{4}$ Cyt. za: Ch. Gr. v. Krockow, Bismarck. Biografia, Warszawa 1998, s. 214, [tyt. oryg. Bismarck. Eine Biografie, Deutsche Verlags-Anstalt, Stuttgart 1997].

45 Cyt. za: J. Feldman, Bismarck a Polska, Kraków 1947, s. 368, [reprint: PWN, Warszawa 1966], [1937'].

46 Cyt. za: L. Trzeciakowski, op. cit., s. 276.

47 Cyt. za: L. Piątkowski, op. cit., s. 131.

48 Chodzi tu o tak zwaną Wochenblattpartei (Partię Tygodnikową) czyli konserwatywno-liberalne środowisko skupione wokół Augusta Moritza von Bethmann - Hollwega (1795-1877) i ukazującego się w latach 1851-1861 tygodnika o orientacji probrytyjskiej i antyrosyjskiej. Wspomniany periodyk nosił tytuł: Preußisches Wochenblatt zur Besprechung politischer Tagesfragen (Tygodnik Pruski do omówienia politycznych kwestii dnia), w skrócie Tygodnik Pruski. Zob. W. Seemann, 
jedno utkwiło mi w pamięci, memoriał, który rzekomo został opracowany w ministerstwie spraw zagranicznych przez cesarza Mikołaja jako pouczenie dla następcy tronu”. Była to przeróbka apokryfu, który ongiś sporządził Napoleon I i przedstawiał jako niby odnaleziony testament Piotra Wielkiego. Jest w nim mowa, że polityka rosyjska musi być wymierzona przeciwko wszystkim państwom i realizowana w celu panowania nad światem (zum Zwecke der Weltherrschaft $)^{49}$.

Drugie z możliwych zagrożeń jakie niosło ze sobą widmo „polsko-rosyjskiego zbratania” to restytucja państwowości polskiej dokonana z inicjatywy Rosjan, wcześniej obmyślana, jak wyraził się Bismarck, „w Petersburgu na bazie «teorii Wielopolskiego" Wielopolskischen Theorien $)^{50}$, korespondujących z pragnieniem s. Konstantego Mikołajewicza Romanowa (1827-1892) by stać się „wicekrólem Polski (Vicekönig von Polen)" ${ }^{1}$ jako rosyjskiej sekundogenitury.

\section{Aspiracje Polaków a panslawizm}

Dla Prus-Niemiec Bismarck przewiduje trzy teoretyczne wzorce zachowań: przyglądać się biernie antyniemieckiej ekspansji wzbierającego panslawizmu, uprzedzić Rosję i samemu zagrać polską kartą, (ale ta może się okazać bronią obosieczną) bądź zachowywać się tak jakby („teorii Wielopolskiego”) w „kwestii polskiej” w ogóle nie było. W tym ostatnim, zalecanym zresztą, wariancie należy doprowadzić do tego by raz na zawsze stała się ona jedynie obiektem dociekań historyków. $\mathrm{Na}$ marginesie zauważmy, że dwóch Polaków, którzy cieszyli się szczególnie złą sławą u Bismarcka to wieczny rewolucjonista Ludwik Mierosławski (1814-1878) i pochodzący z przeciwległego obozu ultralojalistyczny margrabia Aleksander Wielopolski (1803-1877). To tylko pozorny paradoks - w odczuciu Bismarcka obydwu łączyła nienawiść do Niemiec. Pierwszy pragnął ich destrukcji za pomocą zrewoltowanych niemieckich mas plebejskich rzekomo walczących o swe własne społeczne wyzwolenie a drugi wykorzystując potencjał rosyjskiego państwa, którego warstwy przywódcze ulegną uprzednio fascynacji ideologią panslawizmu. Oczywiście takiej jego mutacji, która najbardziej uwzględniałaby interesy polskie, natomiast rosyjskie czy ogólnosłowiańskie traktowała czysto instrumentalnie.

Bismarck ostrzega, że każde podejmowanie tematów polskich jest bardzo groźne, gdyż Polacy są najbardziej niesfornym i irredentystycznie nastawionym

Gesellschaft im Aufbruch. Deutschland 1849-1871, Frankfurt am Main 1990, s. 259 i n.

49 O. v. Bismarck, op. cit., s. 127.

50 Ibidem, s. 358.

51 Ibidem. 
elementem spośród „obcych” w Prusach, a potem w Rzeszy. Podjęcie „kwestii polskiej” oznacza jedynie „trudności, które u nas we wzajemnym przeforsowaniu polskich i niemieckich roszczeń w Poznaniu i Prusach Zachodnich i w położeniu Prus Wschodnich z kwestią przywrócenia polskiej niepodległości są nierozerwalnie związane”. Następnie podkreśla, że „geograficzne położenie i wymieszanie obydwu narodowości we wschodnich prowincjach, włączając Śląsk, zmuszają nas otwarcie kwestii polskiej podług możliwości trzymać na jak najpóźniej, kazało się wydawać pożądanym także w 1863 r. otwarcia tej kwestii przez Rosję nie wspierać, lecz na ile mogliśmy, zapobiec temu" ${ }^{52}$. Dla Bismarcka nie ma różnicy kto podejmie kwestię polską: Rosja czy Prusy-Niemcy. Skutki posunięć polonofilskich niezależnie od ich autorstwa będą identyczne. Polonia Restituta upomni się o swe dawne ziemie zachodnie i to nie tylko przedrozbiorowe, co i o Śląsk, nawet, jeśli zostanie wskrzeszona przez Niemców na obszarze zagarniętego Rosji Królestwa Kongresowego. Czy jednak bezpośrednie sąsiedztwo Prus a potem zjednoczonej Rzeszy z Imperium Romanowych nie niesie ze sobą na tyle doniosłych niebezpieczeństw, by lepiej odgrodzić się od niego rachitycznym państwem buforowym (Pufferstaat)?

„Przejąłem kierownictwo ministerstwa spraw zagranicznych” - wspomina Bismarck - „pod wrażeniem, że w powstaniu, które wybuchło 1 I 1863 r. [powinno być chyba 22 stycznia - dop. mój. - M.K.] nie chodziło tylko o interesy naszych wschodnich prowincji, lecz także o dalekosiężne pytanie czy w rosyjskim gabinecie zapanuje przyjazny Polsce (polenfreundliche) czy antypolski kierunek, dążenie do panslawistycznego, antyniemieckiego zbratania Rosjan i Polaków czy przeciwstawne [mu] oparcie rosyjskiej i pruskiej polityki" ${ }^{33}$. Bismarck ujawnia tu tendencję do łącznego traktowania wrogów i przypisywania im wspólnych celów, choć w istocie są one antagonistyczne. Nierozwiązana „kwestia polska” to pięta achillesowa panslawizmu widzianego z perspektywy rosyjskiej. Polaków nie można zniszczyć, zakwestionować ich istnienia ani dowieść, że nie są Słowianami.

Wracając do realnego politycznie panowania Rosji należy zauważyć, że znajdowała się ona w dość kłopotliwym, doktrynalnie, położeniu. Jak można pogodzić program wyzwolenia Słowian od ucisku w sytuacji, gdy jeden z ich szczepów, zamieszkujący jądro swego prymarnego obszaru etnicznego, stał się obiektem represji ze strony państwa - wyraziciela tych wolnościowych haseł!? Nawet poeta Fiodor Iwanowicz Tiutczew ${ }^{54}$ ze swą wielce obraźliwą metaforą Polski jako Judasza Sło-

52 Ibidem, s. 358.

53 Ibidem, s. 351.

54 Fiodor Iwanowicz Tiutczew (1803-1873) - rosyjski poeta (autor ponad czterystu wierszy, początkowo o przyrodzie, potem zaangażowanych politycznie) naraz dyplomata (poseł carski 
wiańszczyzny ${ }^{55}$, mającą służyć rehabilitacji bezwzględnego kursu Rosjan, mógł co najwyżej wypominać Polsce „grzechy przeszłości” - „niesłowiański katolicyzm” i własną ekspansję wschodnią przy uleganiu obcej Drang nach Osten. Tym samym, jedynie wyrażonym sub alia forma, jest ocena moralna wystawioną Polsce przez wojującego panslawistę Nikołaja Jakowlewicza Danilewskiego $(1822-1885)^{56}$, który ,jezuicko-szlachecką Polskę” przyrównał do „ohydnej tarantuli, która chciwie pożera wschodniego sąsiada, nie bacząc, że zachodni sąsiedzi zjadają jednocześnie jej własny odwłok" "G7. Gdyby jednak wsłuchać się w tembr polskich wypowiedzi o Rosjanach z tamtego okresu, skonstatować należy, że wszelkie te "tarantule” i „Judasze” zbytnio nie odstają od poziomu zaciętości werbalnej ich nadwiślańskich adwersarzy, co z pewnością cieszyło Bismarcka. Fakt, iż Polacy prześladowali w przeszłości innych, konkretnie wschodnich, Słowian (z ich szeregów wszak rekrutowali się dyzunicii, czyli prawosławni po wejściu w życie ponurej sławy unii brzeskiej, 6-10 X 1596 r.) w niczym nie usprawiedliwia dziewiętnastowiecznej postawy Rosji w stosunku do jej części dawnej Polski. Zresztą Rzeczpospolita nie głosiła nigdy panslawizmu, co raczej pankatolicyzm, w zgodzie z dewizą Polonia semper fidelis. Brak jest tu, więc, jak w przypadku Rosji, doktrynalnej sprzeczności - wszak Polska przyjmując na siebie ciężar przedmurza katolicyzmu nie czyniła katolików innego języka obiektem swych prześladowań! Wprost przeciwnie, przez ofensywność uniatyzmu sztucznie ich rozmnażała, by następnie objąć „ojcowską” opieką; (inna rzecz, że ze skutkiem dla Rzeczypospolitej żałosnym) ${ }^{58}$.

w Bawarii, potem (od 1838 r.) w Neapolu). W swej twórczości piewca Rosji jako spadkobierczyni tradycji „całego bizantyjsko-prawosławno-słowiańskiego Wschodu” (R. Łuźny, Fiodor Tiutczew. Zarys monografii, [w:] Fiodor Tiutczew, Wybór wierszy, (oprac. R. Luźny), Warszawa 1978, s. XVI.), niektóre jego wypowiedzi są antycypacją późniejszych haseł twórców doktryny słowianofilskiej, zacięty wróg Polski, autor adresu hołdowniczego do gen. „Wieszatiela” z okazji pacyfikacji Auksztoty. Autor pisanego po francusku traktatu Rosja i Niemcy, (München 1844), po artykule Rosja i rewolucja (Sankt-Pietierburg 1849) oraz Папство и римский вопрос (1850) nazwany „rosyjskim De Maistrem à rebours" (zob. A. Bezwiński, Kilka uwag do artykutu Fiodora Tiutczewa "Papiestwo i kwestia rzymska", [w:] Stowianie wschodni, Kraków 1998, s. 113-120).

55 Chodzi o fragment pochodzący z wiersza Fiodora Iwanowicza Tiutczewa Славянин („Привет вам задушевный, братия...”), który poeta napisał z okazji Kongresu Słowiańskiego w Moskwie w 1867 r. - zob. I. F. Tiutczew, Славянам (Привет вам задушевный, братья...), [w:] I. F. Tiutczew, Полное собрание стихотворений, „Советский писатемь”, Leningrad 1987, s. 233-234.

56 Zob. jego niedawno wydaną biografię: T. Stefaniuk, Danilewski. Panslawizm i wielość cywilizacji, Lublin 2006.

57 Cyt za: A. Walicki, op. cit., s. 408.

58 Wielki wróg Rosji-Moskwy i Prawosławia, historiozof rzymsko-katolicki Feliks Koneczny (1862-1949), stwierdza (nie broniąc przecież prawosławnych poddanych Jagiellonów): „Gdyby nie to gubione dzieło brzeskie, byłoby się stawiało we wschodnich prowincjach Rzplitej nadal kościoły, a wszystko co spośród żywiołów etnograficznych [...] lgnęłoby do Kościoła”. (F. Konieczny, Polskie 
Światli ludzie w Rosji zaczynali rozumieć, ku przerażeniu premiera Prus, że panslawizm traci na wiarygodności unikając uporządkowania kwestii polskiej. Cóż bowiem atrakcyjnego dla na przykład maltretowanego w jarzmie osmańskim Bułgara mógł nieść widok polskiego (też słowiańskiego przecież) katorżnika poddanego syberyjskiej „krioterapii” w słowiańskim państwie? A potrzebne było znalezienie jakiegoś salomonowego wyjścia tak, by zaspokoić choćby elementarne pragnienia polskich poddanych, samemu nie osłabiając własnych pozycji. Z kolei polscy konserwatyści skupieni wokół margrabiego Aleksandra Wielopolskiego poczuli, że naród polski może stać się beneficjentem nadchodzących zmian. Dostrzegał to również Bismarck. Jak komentował ten niebezpieczny dla pozycji niemczyzny proces?

„W dążeniach do zbratania (Verbrüderungsbestrebungen) byli z uczestniczących Rosjanie tymi uczciwszymi; ze strony polskiej szlachty i duchowieństwa sukces takich dążeń byłby ciężkim do pomyślenia czy też jako taki do wzięcia pod uwagę jako definitywny cel. Nie było Polaka, dla którego polityka zbratania przedstawiałaby sobą więcej niż taktyczną ewolucję w celu zwodzenia naiwnych Rosjan, jak długo jest to konieczne albo korzystne. Zbratanie jest nie całkiem, ale przecież w przybliżeniu tak samo niezmiennie odrzucane jak to z Niemcami, ostatnie jednak silniej, nie tylko z antypatii wobec rasy, lecz także w przekonaniu, że Rosjanie w państwowej wspólnocie byliby kierowani przez Polaków, Niemcy natomiast nie" 59 . Bismarck postrzega tu polską nację holistycznie, jako jednię ponad kordonami zaborczymi. Polacy są jednym narodem tak w Rosji jak i w Niemczech, i jeśli zamiast uprawiania liberum conspiro i niszczenia sił witalnych w szaleństwie powstań, podejmują grę z władzami swych nowych państw mogą dojść do jakiś kompromisów. Z drugiej strony Bismarck traktuje Polaków jak bezmyślną masę prowadzoną przez szlachtę i duchowieństwo. Tak, zdaniem Bismarcka, tworzy się u Polaków opinia publiczna, świadomość wspólnotowa.

Oczywiście jest to tylko gra, taktyka Polaków, gdyż ich cel to restytucja status quo ante, a na to nie pójdzie żadne z państw zaborczych. Bismarck dotyka tu również polskich kompleksów narodowych - poczucia niższości wobec Niemców a postawy o przeciwległym wektorze w stosunku do wschodu. Jest tu pewna paralela z niemieckim anglofilizmem (cywilizowany Albion versus ,azjatycka Rosja” i Niemcy w równej odległości cywilizacyjnej od obydwu biegunów). Bismarck

Logos a Ethos. Roztrzasania o znaczeniu i celu Polski, „Antyk. Marek Dybowski”, t. 1-2 w jednym tomie, Komorów, s. 341 [reprint, wyd. oryg. Księgarnia Świętego Wojciecha, Poznań-Warszawa 1921]).

59 O. v. Bismarck, op. cit., s.351. 
uważa, że po epoce księcia Antoniego Radziwiłła ${ }^{60}$ nie ma w Prusach-Niemczech postaci na miarę Wielopolskiego, nie dlatego, że Niemcy nie zapewnili elementarnych warunków dla consensusu, lecz z faktu, że Polacy świadomi swego zacofania i niższości nawet nie próbują podejmować gry na nutę lojalistyczną. Nieliczne wyjątki potwierdzają regułę.

Zupełnie inne perspektywy rysują się, zdaniem Bismarcka, przed Polakami w Rosji, gdzie podejmując na fali panslawizmu flirt $\mathrm{z}$ antyniemiecko nastawionymi przedstawicielami władzy mogliby wniknąć głęboko w struktury państwa, a nawet wyrugować z dotychczasowych okowów niemczyznę bałtycką czy wołżańską. Wpłynęłoby to na ogólną postawę Rosji wobec Niemiec.

Bismarck z niepokojem stwierdza, że rosyjski „polonizm” - jak nazywa filopololską postawę niektórych Rosjan, nie ma tylko jednego tj. panslawistycznego źródła, ale także zaczynają sympatyzować z nimi zapadnicy (okcydentaliści) - liberałowie, pobudzani odmiennymi oczywiście kalkulacjami. Zauważa: „Przyjazny Polsce nurt pozostawał w związku ze stającym się w wyższych rosyjskich elitach coraz głośniejszym żądaniem konstytucji. Odczuwano to jako upokorzenie (Demüthigung), że Rosjanie, którzy przecież też są wykształconymi ludźmi, muszą obywać się bez instytucji, które egzystują u innych europejskich ludów, poprzez które mogą mieć coś do powiedzenia w swych własnych sprawach. Ci Rosjanie, którzy domagali się konstytucji, uwydatniali niekiedy usprawiedliwiająco, że Polacy przez Rosjan nie dają się rządzić i że jako bardziej cywilizowani podnosili roszczenie do udziale $\mathrm{w}$ ich rządzie" ${ }^{1}$. O ile panslawistów Polacy interesowali jako Słowianie mogący w zamian za koncesje na niwie narodowej zabezpieczać zachodnią flankę imperium, o tyle liberałów pociągało w Polakach to, co było, w ich rozumieniu, najmniej słowiańskie, a co sprowadzało automatycznie asocjacje ze światem najprawdziwszego Zachodu - demokratyczna predylekcja, obecne u Polaków poczucie przynależności do łacińskiego kręgu kulturowego, itd. Polacy wiec znaleźli się w komfortowej sytuacji będąc języczkiem u wagi zarówno narodowo-konserwatywnych panslawistów jak i liberałów. Oczywiście okcydentaliści nie byli antyniemieccy, ale przecież mogliby się takim stać pod wpływem Polaków, którzy przekonaliby ich, że Zachód to Paryż, a nie Berlin.

${ }^{60}$ Książe Antoni Henryk Radziwiłł herbu Trąby (1775-1833), I ordynat na Przygodzicach, XII ordynat na Nieświeżu, namiestnik (Statthalter) Wielkiego Księstwa Poznańskiego (Großherzogtum Posen), czołowy rzecznik orientacji propruskiej - swoje wpływy opierał na fakcie spowinowacenia z Hohenzollernami (mąż córki brata Fryderyka Wielkiego) - literatura: J. Kozłowski, Administracja Wielkopolski pod pruskim zaborem 1793-1918, Poznań 2000; T. Nowakowski: Die Radziwills. Die Geschichte einer großen europäischen Familie, München 1975.

${ }_{61}$ O. v. Bismarck, op. cit., s. 350. 
Bismarck zdawał sobie jednak sprawę, że o dalszym losie Rosji zadecydują nie panslawistyczni publicyści czy tzw. liberalne salony opiniotwórcze. Zadecydują czynniki władcze Rosji. Dlatego nie należy trwonić czasu na polemiki z panslawistami czy liberałami, lecz oddziaływać wyłącznie na rząd rosyjski. Należy szukać z nim platformy współpracy. Rząd rosyjski nie jest ani panslawistyczny ani liberalny, co nie wróży bynajmniej łatwego zadania, bo nawet taki rząd nie istnieje w próżni i może w końcu spełnić aspiracje Polaków.

„Polonofilski kierunek rosyjskiej polityki” - ocenia Bismarck - „został po to uczyniony by występującą od czasów pokoju paryskiego, a nawet wcześniej żywioną rosyjsko-francuską styczną ożywić, a polonofilski rosyjsko-francuski związek, jak ten, który pobrzmiewał w powietrzu przed rewolucją lipcową postawiłby ówczesne Prusy w ciężkim położeniu. Mieliśmy interes, aby zwalczać w rosyjskim gabinecie partię polskich sympatii także taką w sensie Aleksandra I"62. W egzekutywie Imperium Romanowych toruje sobie drogę inny rodzaj antyniemieckich przeciwności. Nie ma tam co prawda mowy o Polakach jako słowiańskich braciach ani jako forpoczcie cywilizacji okcydentalnej. Jednak występują w arcyważnej roli - jako karta przetargowa w ewentualnym sojuszu z Napoleonem III. Jest to typowe, neutralne światopoglądowo podejście typu guwermentalnego - przejaw rosyjskiej Realpolitik. Ale, szczęśliwie dla Bismarcka, pogląd ten wydaje się miarodajny jedynie dla części państwowych oficjeli. Jak zneutralizować ową „partię polskich sympatii” (Partei der polnischen Sympathien)?

\section{Panslawizm a polski Styczeń, czyli point de rêveries}

Oczywiście Niemcy mogą postawić na tradycję, którą Bismarck nazywa „polityką pokrewieństwa" (Verwandschaftspolitik), oczywiście nie w sensie podobieństw między Słowianami i Germanami, lecz wspólnych małżeństw miedzy dynastami niemieckimi i rosyjskimi, co na stałe wzrosło do pejzażu XIX wieku. Ale akurat więzy familijne, jak pokazała historia, były elementem nacisku Rosji (zwłaszcza Mikołaja I) na Niemcy czy Prusy a nie na odwrót - vide: Punktacja Ołomuniecka (Olmützer Punktation) z dnia 29 XI 1850 r. ${ }^{63}$. Nie można też było liczyć na efekt propagandowy związany z demonizowaniem polskiego niebezpieczeństwa, gdyż aktualnie trzymający ster polityki rosyjskiej nie kierowali się „polityką uczuć” (Gefühlspolitik), lecz racją stanu z wkalkulowanym w nią ryzykiem polskim.

62 Ibidem, s. 352.

${ }^{63}$ Obszerniej na jej temat: M. Kopczyński, op. cit., s. 161, 190. 
Bismarck znalazł inne wyjście. Postanowił zaatakować panslawizm jako rzekomo tożsamy z „polonizmem”. Oczywiście nie mógł sprowadzić panslawizmu do wspólnego mianownika na przykład z dekabrystami i przedstawiać go jako ruch antypaństwowy, zważywszy, że aspirował on nawet do miana oficjalnej ideologii państwowej, a jego teoretycy byli bez wyjątków monarchistami. Co praw$\mathrm{da}$, apelując do etnicznej więzi był raczej wynikiem fascynacji „Ziemią” (a więc w domyśle nie „Państwem”), jednak to za mało, by przypisać mu rewolucyjną genezę. Ale panslawizm, i tu tkwiła szansa Bismarcka, nie pochodził od czynników rządowych, lecz wyrósł z opozycyjnego względem „oficjalnej ludowości” słowianofilstwa i był próbą narzucenia „Państwu” swych ideowych konsekwencji.

Droga rozumowania Bismarcka jest następująca. Rosja, jako najbardziej konserwatywny kraj Europy, winna trzymać się swej dotychczasowej, sprawdzonej dewizy wyrażonej w słynnej trójdzielnej formule ministra oświaty hrabiego Uwarowa ${ }^{64}$. Jak dowodził ów założyciel uniwersytetu kijowskiego, panujący system trzeba oprzeć na „czysto rosyjskich zasadach zachowawczych, jakimi są: „Prawosławie, Samodzierżawie, Ludowość", (Православие, Самодержавие, Народность) one bowiem stanowią ostatnią kotwicę, jaka nas może ocalić i najpełniejszą gwarancje siły i wielkości naszej ojczyzny" ". Rosja, będąc wierna swej tradycji, zdołała wyzwolić się od dominacji tatarskiej, wydobyła się ze stanu atrofii zwanej Wielką Smutą (Смутньь времл), odparła pochód korsykańskiego Aнmuхриста. Stała się wskutek własnej aktywności militarnej państwem wielonarodowościowym (imperium), nigdy dotąd nie pobudzana hasłami panslawistycznymi, które przecież niweczyłyby ideologiczny sens wszelkich azjatyckich czy amerykańskich (Alaska) zdobyczy. Nawet dotychczasowe sukcesy w zmaganiach z Portą Otomańską zawdzięcza Rosja nie realizacji idei oswobodzenia Słowian południowych, lecz mądrości swych władców i ich otoczenia, w którym znajdowali się nie tylko Rosjanie, co licznie reprezentowani bałtyccy i wołżańscy Niemcy. Jednym z elementów tradycji jest przyjaźń z Niemcami, a nie ze słowiańskimi buntownikami, którzy względem swej prawowitej władzy (tureckiej) artykułują ten sam typ emocji, co Polacy wobec realności rosyjskiego panowania nad Wisłą. Panslawizm jako przerwanie łańcucha tradycji jest rewolucją! W rozwoju Rosji odnajduje następną współzależność: obok „nihilistów” (w tej liczbie dekabryści potem narodowolcy,

${ }^{64}$ Hrabia Siergiej Siemionowicz Uwarow (1786-1855), rosyjski pisarz i mąż stanu, 1833-1849 minister oświaty Cesarstwa Rosyjskiego, twórca wielu placówek naukowych (między innymi uniwersytetu kijowskiego) ale także muzeów i bibliotek. Więcej: A. Zamostianow, Граф С. С. Уваров - Министр Народного Просвещения, http://anguium.narod.ru/200_4.html, [dostęp dn. 14 VII 2013 r.].

${ }^{65}$ Cyt. według. A. Korniłow, Kyрс истории Poсcии XIX века, Moskva 1912, s. 75-76. 
wreszcie marksiści) występują również przedstawiciele „wyższego rosyjskiego społeczeństwa" (böheren russischen Gesellschaft), którzy uchodząc za prawomyślnych monarchistów i absolutystów podnoszą hasła wywrotowe, w sensie braku odniesień do rosyjskiej tradycji. Monarchizm nie może być papierkiem lakmusowym wierności ustrojowi państwa. Fakt, że panslawiści są oddani dynastii o niczym jeszcze nie przesądza, skoro powołanie Rosji widzą w aliansie z nurtami rewolucyjnymi w narodach słowiańskich (jedynie Polakom - jako swej „kwestii wewnętrznej” - czyniąc (na razie!) wyjątek). Zadaniem państwa konserwatywnego i w formie (самодержавие) i w treści (Православие, народность) nie może być wspieranie ruchów antypaństwowych poza własnymi granicami. Idealna przyszłość dla Rosji to, w marzeniach Bismarcka, jej trwanie w trójdzielnej formule Uwarowa jakby opatrzonej klauzulą non varietur, z silnie zakorzenioną ideą braterstwa broni roku 1813 r. „Przeciw-stronnictwo [w stosunku do panslawizmu - M.K.] chciałbym konserwatywnym nazwać” - pisze do ministra hr. Bernstorffa z 9 III 1863 r. „Do niego należy całym sercem cesarz, generałowie, niemieccy mężowie stanu, którzy nie ufają Francji i uświadamiają sobie niemożliwość polubownego porozumienia z polskimi narodowymi roszczeniami (National-Ansprüchen)"66.

Z perspektywy lat dziewięćdziesiątych wspomina: „Nie dało się wtedy z pewnością przewidzieć czy i jak długo ten polityczny kapitał carskiej przyjaźni da się praktycznie zużytkować. W każdym bądź razie wyczuwał to prosty, zdrowy rozsądek ludzki, aby nie dać go wpuścić w posiadanie naszych wrogów, których widzieliśmy w Polakach, polonizujących Rosjanach (polonisirenden Russen) i w ostatnim zamknięciu prawdopodobnie także we Francuzach"67.

Nie wiadomo, jakimi torami potoczyłyby się losy „partii polskich sympatii” (Partei der polnische Sympathien) na dworze petersburskim, gdyby nie szaleńczy zryw $1863 \mathrm{r}$.

Nie oznaczał on jeszcze końca stronnictwa filopolskiego lecz otworzył drogę pod konwencję Alvenslebena. „Militarna konwencja, którą generał Gustaw von Alsvenleben zawarł w lutym 1863 r. w Petersburgu [dokładnie 8 lutego - dop. mój - M.K.], miała dla pruskiej polityki bardziej dyplomatyczny niż militarny sens. Przedstawiała w gabinecie rosyjskiego cesarza odniesione zwycięstwo pruskiej polityki nad polską, która była reprezentowana przez Gorczakowa, wielkiego księcia Konstantego, Wielopolskiego i inne wpływowe osoby. Rezultat polegał na bezpośredniej rezolucji cesarskiej w przeciwieństwie do ministerialnych dążeń" ${ }^{\prime 68}$.

66 O. v. Bismarck, op. cit., s. 359 (przypis wydawcy cytującego Bismarck-Jahrbuch, VI, s. 172 i n.).

67 Ibidem, s. 354.

68 Ibidem, s. 358-359. Dodać należy, że w jednym z mało znanych epizodów miała ona 
Zauważmy, że Bismarck nie dostrzega podmiotowości polskiej polityki ugodowej skoro margrabiego Wielopolskiego - czołowego jej wyraziciela, sytuuje wśród filopolskich polityków ... rosyjskich, a jego możliwości ocenia wprost proporcjonalnie do zakorzenienia na dworze carskim, a nie wpływów (choćby i nikłych) w społeczeństwie polskim. $Z$ drugiej jednak strony nie obawia się skutków powstania, którego wybuch polepsza jedynie pozycję przetargową Prus, lecz właśnie powikłań wywołanych „polsko-rosyjskim zbrataniem” (polnisch-rusischen Vebrüderung). A przecież jest ono do pomyślenia wyłącznie jako jedno z następstw polityki Margrabiego, a nie tej Langiewicza czy Traugutta.

Można powiedzieć, że styczeń 1863 r. jest darem niebios dla wszystkich rosyjskich przeciwników ustępstw w kwestii polskiej w Rosji i dla samego Bismarcka. Oto wszczynając rebelię Polacy dali wyraźny sygnał, że nie pragną restytucji stosunków sprzed 1830 r., lecz żądają przecięcia wszelkich związków z Imperium Romanowych na obszarze swej preponderancji etnicznej a nawet Ziem Zabranych. Nie oznacza to, że Rosja staje się automatycznie zakładniczką Prus, w poczuciu bezradności oczekując wsparcia z ich strony. Sam Bismarck podkreślał, że „rosyjskie oddziały były dostatecznie silne, a sukcesy insurgentów istniały w większej części tylko w zamawianych w Paryżu, fabrykowanych w Myslowitz [dziś Mysłowice - M.K.], datowanych z granicy, z placów bitewnych albo z Warszawy, częściowo prawdziwie bajkowych raportach, które najpierw ukazywały się w jednej berlińskiej gazecie a potem robiły rundę po europejskiej prasie" ${ }^{69}$. Ale wobec doniosłości międzynarodowych not protestacyjnych, zwłaszcza austriackich „sześciu punktów" (sechs Punkten) z 18 VI 1863 r., gdzie pod numerem drugim pojawiło się godzące w suwerenność państwową Rosji żądanie „Zgromadzenia Narodowego, które weźmie udział w ustawodawstwie kraju i posiądzie środki skutecznej kontroli"70, kraj ten w pełni skorzystał z owoców Alvenslebenowskiej konwencji. Bismarck bardzo celnie scharakteryzował jej znaczenie dla przegrupowania sił i sympatii tak na dworze, jak i w społeczeństwie rosyjskim.

„Układ polityczno-militarnej natury, który Rosja zawarła z germańskimi przeciwnikami panslawizmu przeciwko „bratniemu plemieniu” (Bruderstamm) [cu-

również znaczenie stricte militarne. Chodzi mianowicie o incydent z 28 IV 1863 r., gdy w walce z powstańcami [w oficjalnej nomenklaturze nie używało się słowa „powstańcy” (повстанщъь) tylko „buntownicy” (мятежники)] rosyjski odział pościgowy wtargnął w granice państwa pruskiego, a nawet wkroczył do miasta Hohesalza (dziś: Inowrocław). Zob. hr. Ch. v. Krockow, op. cit., s. 305, s. 107 (w przypisie, nb. zawierającym błąd drukarski - podano datę 1893 r.) oraz pracę: K.-E. Jeismann, L. Trzeciakowski, Kwestia polska w polityce mocarstw europejskich w XIX wieku: konwencja Alvenslebena $z 8$ lutego 1863 r., Warszawa 1998. Tekst konwencji ibidem, s. 40.

69 O. v. Bismarck, op. cit., s. 360.

70 Cyt według: Ibidem, s. 355. 
dzysłów pochodzi od Bismarcka - dop. mój - M.K.] był rozstrzygającym ciosem w zamiary stronnictwa polonofilskiego (polonisirende Partei) na rosyjskim dworze [...] Konwencja była udanym posunięciem szachowym, który zadecydował o partii, którą wewnątrz rosyjskiego gabinetu grały przeciwko sobie antypolskie monarchiczne i polonizująco panslawistyczne wpływy"71.

Gdyby nie powstanie styczniowe mógłby zapewne Bismarck latami przekonywać przywódców rosyjskich o tym że panslawizm to „rewolucja” i niebezpieczeństwo dla samej Rosji, z różnym skutkiem. Powstanie styczniowe wystarczyło za dziesiątki wywodów, uzasadnień i przykładów.

Panslawizm niebędący w istocie żadną „rewolucją”, lecz propozycją środowisk wiernych Tronowi, aby przekształcić imperium rosyjskie w centrum dowodzenia wszystkimi Słowianami świata, nie skończył się oczywiście z powstaniem polskim. Skończyły się natomiast wszelkie szanse, że panslawizm, choć wrogi co do zasady „jezuickiej” Polsce w końcu znajdzie z nią jakiś modus vivendi przeciwko żywiołowi germańskiemu jako wspólnemu i największemu wrogowi. Tym samym, że jakaś forma podmiotowości polskiej będzie Rosji do czegokolwiek potrzebna. Słowa point de rêveries, pasują tu o wiele bardziej niż w 1856 r., gdy zostały wypowiedziane.

\section{Konkluzje}

Istotnym mankamentem wywodów Bismarcka jest łączenie sukcesów kwestii polskiej w Rosji ze wzrostem popularności ruchu panslawistycznego, podczas gdy eksponenci tego nurtu w istocie traktowali Polaków jako prawie że zło konieczne a nie zbiorowość, którą dla haseł wszechsłowiańskich należy bezdyskusyjnie pozyskać. Oczywiście panslawiści musieliby, chcąc pozostać w zgodzie z własnymi hasłami, uczynić jakieś gesty pojednawcze w stosunku do żywiołu polskiego, choć zapewne niewystarczające dla trwałego pozyskania poparcia polskiej opinii publicznej. Ale pamiętać należy, że wszelkie koncesje Wielopolski wywalczył od rządu rosyjskiego, który co do zasady Bismarck odbierał jako sojusznika Prus, a nie w wyniku porozumień z panslawistami (zresztą ci przecież nie rządzili, więc nie decydowali). Ponadto ruch panslawistyczny nieco zdemonizowany przez Bismarcka występował bardziej przeciw niemieckiemu charakterowi państwa Habsburgów, oraz przeciw Porcie Otomańskiej, aniżeli przeciwko Prusakom-Niemcom; na sztandarach niósł hasło wyzwolenia Bułgarów oraz Serbów, ale bałkańskich, a nie łużyckich.

\footnotetext{
${ }^{71}$ Ibidem, s. 360 .
} 
Jednocześnie sami Polacy nie byli ofertą współdziałania z Rosją w ramach panslawizmu a przeciw „Germanom”, zbytnio zainteresowani. Żyjący wówczas Edward Romer pisał: „[...] zdaje się moskalom [z małej litery - dop. mój. - M.K.] czy słowianofilom, że kazić dzieło rąk Boskich, z dwóch plemion jednego pochodzenia u źródła robić jedno koryto w ich biegu jest rzeczą łatwą albo godziwą. - Kiedy całe nasze kształcenie się, cały pęd życia narodowego, są zupełnie inne, wbrew z ich życiem sprzeczne. [...] Mogą więc Moskale mieć zdolność od Boga, ale inną, nie naszą i wszelkie spożywanie nas będzie zawsze przeciwne Boskiej woli, a męczarnią dla nas"72.

Oczywiście zaznaczyły swą obecność również inne postawy. Marszałek szlachty guberni grodzieńskiej Wiktor Wacław Starzeński (1826-1882) został przyjęty na audiencji przez panującego monarchę ${ }^{73}$, która miała miejsce 20 lub 21 XI (2 lub 3 XII) 1862 r. w dawnej stolicy carów ${ }^{74}$. „Rosji przyznawał prymat misji cywilizowania Azji, zaś zadaniem Słowian Zachodnich, zjednoczonych pod berłem dynastii Romanowych, stać się miało powstrzymanie ekspansji świata germańskiego"75 - relacjonuje spotkanie polski autor. Czytając o rozmiarze zadań jaki zdaniem Starzeńskiego miał za zgodą Rosji przypaść samodzielnie Polakom (Słowianom Zachodnim), widzimy, że ów zwolennik ugody z caratem był równie oderwany od rzeczywistości co i, w inny sposób, późniejsi insurgenci.

Ale i w tym przypadku polityk polski antyszambrował u cara, nie udzielając się bynajmniej na zjazdach propaństwowych, lecz nie rządzących państwem, panslawistów.

Z pewnością najważniejsze było to co polscy realiści czynili nie na Ziemiach Zabranych (czy jak kto woli w Kraju Zachodnim, 3anaдном краe), lecz w Królestwie. Bismarck w swych przemyśleniach perfekcyjnie oddał niebezpieczeństwo, jakie dla Prus nawet już nie w kontekście zjednoczenia Niemiec, co nawet dla państwowego status quo stanowiła perspektywa „polsko-rosyjskiego zbratania”, przed którą alarmował rodaków. Była ona trudna do ziszczenia, ale póki nie doszło do zbrojnego uzewnętrznienia antyrosyjskich obsesji w 1863 r., wciąż możliwa do przeprowadzenia. Uosabiał to zagrożenie Aleksander Wielopolski, którego suk-

${ }^{72}$ E. Romer, Rocznik na 1862 r., zapis z dnia 20 III (1 IV n. s.) 1862 r., cyt. za: D. Szpoper, Pomiędzy caratem a snem o Rzeczypospolitej. Myśl polityczna i działalność konserwatystów polskich w guberniach zachodnich Cesarstwa Rosyjskiego w latach 1855-1862, Gdańsk 2003, s. 516.

${ }_{73}$ Był nim Aleksander II (1818-1881), od 1856 r. car Wszechrosji; zob. monografię: L. M. Liaszenko, Царь-Освободитель. Жизнь и деяния Александра II, Moskva 1994. Po polsku dostępna jest dużo słabsza, tłumaczona z angielskiego praca (oryginał powstał w jęz. rosyjskim): E. Radziński, Aleksander II. Ostatni Wielki Car, Warszawa 2005.

74 D. Szpoper, op. cit., s. 542.

75 Ibidem, s. 547. 
cesu (podwójnego, bo i w społeczeństwie polskim, i u Rosjan) przyszły twórca Drugiej Rzeszy Niemieckiej w sposób widoczny obawiał się. Dnia 26 III 1861 r., w liście kierowanym do ukochanej siostry Malwiny ${ }^{76}$, Bismarck użył znamiennych słów: „Bijcie ich tak, aby im przeszła ochota do życia. Co do mojej osoby rozumiem ich sytuację, ale, jeśli chcemy żyć nie pozostaje nam nic innego jak ich zniszczyć"77. Są one wielekroć przytaczane przez licznych autorów, dopatrujących się w urywku z prywatnej korespondencji manifestu politycznego. Tymczasem jest to raczej pokłosie głębokich i skrywanych frustracji autora wobec perspektywy wyjścia nieprzewidywalnej Rosji z jej dotychczasowych kolein rozwojowych to jest historycznego pojednania z Polakami celem antyniemieckiego współdziałania. Trzeba tępić Polaków w Prusach zanim ci po porozumieniu z Rosją staną się jej forpocztą nad Wartą. Niebezpieczeństwo w opinii tego par exellance realnopolitycznego męża stanu stanowił, jak dowiedliśmy, Wielopolski, jego polityka i filopolscy Rosjanie pozyskani przezeń nad Newą, natomiast powstanie styczniowe to... zrządzenie losu dla monarchii Hohenzollernów tak w kontekście jej dalszego trwania, jak i urzeczywistnienia niemieckiej jedności, co miało być, jego zdaniem, powołaniem Prus (der deutsche Beruf Preußens).

Tymczasem: „Margrabiemu z jego kunktatorstwem politycznym przypisywano” - zauważa słusznie jego współczesny biograf - „rezygnację z wielkich ambicji narodowych; on zaś rezygnował jedynie z narodowych złudzeń i narodowej frazeologii, z zastępowania racji - demonstracją. Ci, którzy przeciwstawiali mu konieczność „budzenia narodowego ducha” odnieśli jednak tryumf i powtarzają swoje zaklęcia do dziś”78.

76 Malwine von Arnim-Kröchlendorf de domo Bismarck (1827-1908), siostra Żelaznego Kanclerza, 1844 w rodowym majątku Schönhausen poślubiła posiadacza ziemskiego Oskara von Arnim-Kröchlendorffa (1813-1903) landrata w Angermünde i późniejszego członka pruskiej Izby Panów oraz deputowanego Reichstagu. Zob. Ch. Gr. v. Krockow, op. cit, s. 28, 76, 86, 92 i 182.

77 W oryginale: Schlagen Sie so, daß ihnen die Lust am Leben vergeht. Ich, für meine Person, verstehe ihre Situation aber wenn wir leben wollen, bleibt uns nicht anderes übrig, als sie zu vernichten. Cyt. za: A. S. Jerusalimskij, Bismarck. Diplomatie und Militarismus, wydanie drugie, Berlin 1983 [1970'], s. 51, [tyt. oryg. A. S Jerusalimskij, Бисмарк. Аипломатия имилитаризм, Moskva 1968 - tłum. I. Zeisler].

78 A. Żor, Ropucha. Studium odrzucenia, Toruń 2007, s. 472. O dziwo pierwsza praca monograficzna poświecona Wielopolskiemu na ziemiach polskich była mu dość przychylna. Jej autor to galicyjski konserwatywny historyk, członek-korespondent Akademii Umiejętności Henryk Lisicki (1839-1899) - zob. H. Lisicki, Aleksander Wielopolski, 1803-1877, t. 1-4, Kraków 1878-1879. Jednak natychmiast spotkał się on z namiętną ripostą Agatona Gillera (1831-1887), ex-sybiraka i byłego przewodniczącego Tymczasowego Rządu Narodowego w powstaniu styczniowym - zob. A. Giller, Aleksander hr. Wielopolski margrabia Gonzaga Myszkowski, Lwów 1878. I ten drugi nurt ocen dominuje. 
Nie tylko wspomniane uchwały Sejmu i Senatu potwierdzają trafność tej opinii. Również faworyzowanie konkretnych ocen, czemu służyło rocznicowe wznowienie książki efemerydycznego premiera i publicysty Artura Śliwińskiego (1877-1953) Powstanie styczniowe ${ }^{79}$, wpisuje się idealnie w ten jednolity manieryzm interpretacyjny. Przeczytamy tam między innymi, cokolwiek miałoby to oznaczać: „Powstanie styczniowe wznosząc sztandar niepodległości przegrało walkę, ale nie przegrało idei walki o niepodległość" $"$.

Będąc w zgodzie z zaprezentowanymi poglądami Bismarcka, trzeba by raczej skonstatować, że powstanie styczniowe, co do tego panuje całkowita zgoda, „przegrało walkę” nadto owszem „nie przegrało idei”, nawet ją wygrało, tyle, że chodzi o ideę zjednoczenia Niemiec, na które Rosja po doświadczeniach z Polakami i w poczuciu wdzięczności za konwencję Alvenslebena, niebawem wyraziła przyzwolenie.

79 A. Śliwiński, Powstanie styczniowe, Warszawa 2013, posłowie (Refleksje o Powstaniu Styczniowym $w$ 150-lecie jego wybuchu) M. M. Drozdowski, [wydanie pierwsze: M. Arct, Warszawa 1919, wydanie drugie: ibidem, 1921, trzecie: Państwowe Wydawnictwo Książek Szkolnych, Lwów 1938].

80 A. Śliwiński, op. cit., s. 193. 